\title{
Onko osaamisella sukupuoli?
}

\author{
Anja Heikkinen \& Ulla Huttunen
}

Työn sukupuolen mukainen jako vallitsee kaikkien Euroopan maiden työ- ja koulutusmarkkinoita. Ammatillista osaamista ja sukupuolta koskevat käytännölliset ja tieteelliset keskustelut kohtaavat kuitenkin harvoin. Artikkeli kuvaa kansainvälistä tutkimusta, jossa selvitetään osaamisen sukupuolittumista ja sen ylittämisen mahdollisuuksia työpaikkojen ja oppilaitosten kasvatuskäytännöissä. Suomalaisten tutkimushaastattelujen alustavassa luennassa niin miehet kuin naiset pitävät osaamisia sukupuolettomina. Syvempi tulkinta edellyttää osaamis- ja gender-diskurssien kriittistä hyödyntämistä.

\section{Genderqual-projekti ja osamisen sukupuoli}

Miltä miespäivähoitajan työ tuntuu? Miksi nainen ei uskaltaudu sähköasentajaksi? Miksi kreikkalaisvanhemmat eivät halua miestä hoitamaan lastaan? Ovatko suomalaiset keittiöt suopeita niin miesten kuin naistenkin osaamiselle? Onko osaaminen siirrettävissä ammatista toiseen ja sääteleekö siirtoa sukupuoli enemmän kuin ammatti? Ammatillisen osaamisen ja taitojen sukupuolittumista ${ }^{1}$ sekä sen ylittämisen mahdollisuuksia tutkitaan Jyväskylän yliopiston kasvatustieteen laitoksella meneillään olevassa EU:n rahoittamassa Genderqual-projektissa ("Transcending gendered features of key qualifications for improving options for career choice and enchancing human resource potential"). Tutkimus on alkanut keväällä 2000 ja se jatkuu vuoden 2002 kevääseen saakka. Projektin koordinaattorina on Flensburgin yliopisto Saksasta, muina partnereina Jyväskylän ohella Lontoon, Patrasin ja Evoran yliopistot.
Yhteiskunnallisen kokonaistyön ja siihen valmistamisen horisontaalinen ja vertikaalinen jako miesten ja naisten kesken näkyy selvästi kaikkien Euroopan maiden työmarkkinoilla ja koulutuksessa. Kaikkialla Euroopassa naiset etupäässä keittävät, siivoavat, kasvattavat ja hoivaavat, miehet kuljettavat, rakentavat, suunnittelevat ja johtavat. (ks. Kauppinen-Toropainen 1991, Kolehmainen 1999, Tilastokeskus 2001). Genderqualhanke kysyy ydinosaamisen ja sosiaalisen sukupuolen suhdetta ja sukupuolittamisen ylittämisen mahdollisuutta eurooppalaisessa tutkimusasetelmassa. Hankkeen tulisi tarkastella osaamista, taitoja ja niiden sukupuolittumista sekä oppilaitosten ja työpaikkojen kasvatuskäytänteiden vaikutuksia niihin kansallista ja kansainvälistä tasoa keskusteluttaen. Myös ammatillisia siirtymiä ja työmarkkinoiden muutoksia tulisi analysoida. Tärkein tavoite on tuottaa kehittämisehdotuksia eurooppalaisille ammattikasvatuksen suunnittelijoille ja käytännön toimijoille. Catering-alalta, sähkötekniikasta ja päivähoidosta valittiin työntekijäasteen ammatit: kokki/tarjoilija, säh- 


\section{A R T I K K E L I T}

köasentaja ja päivähoitaja, jotka löytyvät likipitäen samaa tarkoittavina partnerimaissa. Kansainvälinen hanke ohjaa käytettävää sanastoa, aineiston hankintaa ja analyysiä, mutta tutkimusasetelman työstäminen on vaikeaa, kun partnerit etenevät eri tahtia ja esittävät välituloksia eri tavoin. Yhteisen teoreettinen ja metodologinen pohdinta uhkaa pysähtyä pinnalliseen maiden ja ammattien vertailuun.

Petri Sipilä (1998) kysyy, onko sukupuoli eettisesti oikein. Työ ja sen jakaminen, ammatit sen kulttuurisesti instituoituina muotoina, ovat perustavia elämän ylläpitämiselle. Kasvatuksellisesti Sipilän kysymystä voisi jatkaa: onko ammatillisten osaamisten erilaistuminen sukupuolen mukaan oikein, pitäisikö ja voiko sille tehdä jotain?

\section{MAHDOTON YHTÄLÖ: ydinosaaminen + sukupuoli}

Monikulttuurisuuden ja ohjelmallisuuden ohella Genderqual-hankkeen haasteena on ydinosaamis- ja sukupuolittumista koskevien käytännöllisten ja tutkimusdiskurssien erillisyys. Olemme omalta osaltamme yrittäneet työstää nämä huomioonottavaa tutkimusasetelmaa.

\section{(Ydin)osaminen}

Pidämme tärkeänä erottaa ammatillista osaamista koskevan keskustelun neljä osittain erillistä tasoa. Genderqual-hanketta normittava poliittishallinnollinen diskurssi tapahtuu pääasiassa EU:n ja siellä omaksutun termistön puitteissa. Tutkimusdiskurssi palvelee osittain sitä, mutta etenkin kansallisesti ammatillista opettajankoulutusta ja opettajien toimintaa. Suomessa eri koulutusalojen opetussuunnitelmat ilmentävät työelämän ja opettajien välistä keskustelua toimi- ja ammattialojen ja ammattilaisuuden kehittämisestä. Ammattikasvatuskäytäntöjen tasoinen keskustelu taas tapahtuu oppilaitoksissa ja työpaikoilla eri ammattilaisryhmien, opettajien ja opiskelijoiden kohtaamisissa.

Työnsosiologiassa, ammatti-ja aikuiskasvatuksessa

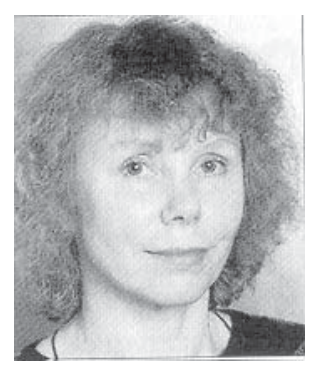

Anja Heikkinen

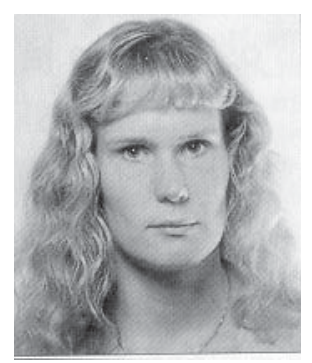

Ulla Huttunen

ja koulutuspolitiikassa vaikuttaneet saksalaisvetoinen avainkvalifikaatio- ja angloamerikkalaisvetoinen ydinkompetenssidiskurssi ovat perinteisesti olleet sukupuolineutraaleja tai -sokeita (esim. Nijhof\&al 1998, Wolf 1995, Reetz 1990). Saksalainen keskustelu aktivoitui 1970-luvulla yhtäältä uusien ihmiskeskeisten tuotanto- ja työnorganisointimuotojen kehittelyn, toisaalta joustavuutta ja osallistamista edistävien ammattikoulutusreformien perustelemisen takia (Reetz 1990, Arnold 1997). Avainkvalifikaatioiden piti vähentää työhön suuntautuvan koulutuksen ammatillista eriytymistä, olla käytettävissä ja siirrettävissä mihin työhön tahansa. Kasvatuksellisesti oli kyse myös ammatillisen koulimisen (Qualifizierung) ja yleissivistyksen (Bildung) välisen eron ylittämisestä. Nykyään korostetaan avainkvalifikaatioiden merkitystä ammattikasvatuksen kehittämiseksi ennakoivaksi ja mahdollistavaksi, “evolutionaariseksi”, yksilöllistä luonteenkasvatusta tukevaksi. Avainkvalifikaatioiden luonnehtiminen yksilön sosiaaliseksi kompetenssiksi on yleistynyt. Angloamerikkalaisessa ydinkompetenssidiskurssissa on yritysjohtamiseen ja kouluopetukseen kohdistuvat suuntaukset. Edellisessä ydinkompetenssit määritellään yrityksen kilpailukyvyn kannalta keskeisiksi osaamisiksi. Koulu- 
kontekstissa puhutaan perus- tai yhteisistä taidoista, nykyään ydin- tai avaintaidoista. (Kelly 2001) Yhteistä diskursseille on kompetenssien perustuminen ulkoiseen, mitattavaan käyttäytymiseen ja mahdollisuus niiden standardoituun, julkiseen arvioimiseen oppimispaikasta riippumatta. (Wolf 1995) Kommunikointi-, lasku- ja IT-taidot, yhteistyötaidot, oppimaan oppiminen ja ongelmanratkaisu ovat tyypillisiä ydinkompetensseja. Ne ovat yleistettäviä, siirrettäviä ja opittavissa erilaisissa ympäristöissä.

Suomalaisessa työnsosiologiassa ja aikuiskoulutuksessa ydinosaamista luonnehditaan usein "tiedot, taidot ja asenteet" jäsennyksen ja työn markkinavaatimusten perustalta. Työtehtävässä toimimisen katsotaan edellyttävän osaamiselta tiedollisen perustan sekä konkreettisia taitoja, joita voidaan hankkia koulutuksen tai kokemuksen avulla. Osaamisen normatiivinen orientaatio tarkoittaa työssä ja työyhteisössä vaadittavia asenteellisia valmiuksia. (esim. Koivisto \& Koski 1999, 74.) Suomalaisen ammattikasvatuksen poliittishallinnollista ja tutkimuskeskustelua vallitseva tulkinta ydinosaamisesta löytyy opetussuunnitelmien valtakunnallisista perusteista, jotka soveltaen ovat voimassa aikuiskoulutuksessa. Eri koulumuodoille yhteisten tavoitteiden ohella ammatillisten koulutusalojen yhteisinä ydinosaamisina pidetään oppimaan oppimisen, ongelmanratkaisu-, vuorovaikutus- ja viestintä-, yhteistyö-, esteettisiä ja eettisiä taitoja. Niin yhteiset tavoitteet kuin ammattialojen yhteinen ydinosaaminen tulisi sisällyttää oppilaitoskohtaisiin opetussuunnitelmiin ja koko oppilaitostoiminnan organisointiin. Ne pitäisi sisällyttää myös koulutusalakohtaisiin opetussuunnitelmiin ja oppimisen arviointiin. Yleisimmin ne näkynevät kaikille yhteisissä opinnoissa, jotka voivat olla enemmän tai vähemmän ammattialaan integroituja. Vaatimus jatko-opintokelpoisuudesta ja yhdistelmäopintojen suorittamisesta keskittää yhteiset tavoitteet ja ydinosaamisen lukio-opintoihin rinnastuviin yleissivistäviin kursseihin. Genderqual-tutkimuksen kannalta tärkeimpiä ovat alakohtaisissa opetussuunnitelmissa mainitut perusosaamiset, sillä ne ovat lähinnä kasvatuskäytänteissä rakentuvaa ydinosaamista.
Poliittis-hallinnollisissa ja tutkimusdiskursseissa avainkvalifikaatiot tai ydinkompetenssit ovat yksilöllisiä, abstrakteja ja epäpersoonallisia (Ainley 1993, Wolf 1995). Kun työvoiman taitojen hallinnointi koulumaisen ammattikasvatuksen avulla on tullut monimutkaisemmaksi, kalliimmaksi ja tehottomammaksi, ydinosaamisista etsitään ratkaisua elinikäisen oppimisen organisoimiseen. Niiden on tarkoituskin irtautua ammatillisen osaamisen kollektiivisista ja kokemuksellisista merkityksistä. Kun muodollinen, julkisesti kontrolloitu kasvatus keskittyy yleisiin osaamisiin ja taitoihin, voidaan työ- ja organisaatiospesifi jättää työssä tai muualla opittavaksi. Vaihtoehtona olisi ymmärtää ammatillinen osaaminen yhteiskunnallisen kokonaistyön kulttuurisen määrittelyn osaksi. Tässä kulttuuri tarkoittaa merkitysten, tulkintojen, arvojen ja eetoksen sekä niiden objektivoitumisen tilaa, niiden tekemistä ja tuottamista, niiden (uudelleen)luomista ja aikaansaamista (Heikkinen ym. 1999, 6). Ammatti ilmentää yksilöiden ja kollektiivien välisten vuorovaikutusten ja neuvottelujen historiallisesti muuntuvaa tulosta. Yksilön persoonallisen maailmasuhteen osana, osallisuutena yhteiskunnalliseen kokonaistyöhön, osaaminen ja taidot ovat samassa merkityksessä kehollisia ja persoonallisia kuin tietokin. (ks. Polanyi 1983, Siltala 1999.)

Genderqual-hankkeen tulisi tutkia ydinosaamista erityisesti kasvatuskäytänteiden tasolla. Ammatillisen osaamisen kehittymisessä koulun ja opettajien tulkinnat, työstä asettuvat tulkinnat ja yksilöiden tulkinnat itsestään muokkavat toisiaan. Osaamisen ammatillisuus perustuu työn kohteen ja sen kanssa toiminnan erityislaatuun. Esimerkiksi päivähoidossa lapsen fyysiset ja psyykkiset tarpeet asettavat lähtökohdan päivähoitajan työlle, määrittävät osaamisalueet. Taidolla tarkoitamme työntekijän tapaa tehdä työtään, vaikkapa päivähoitajan työtapoja hänen vastatessaan lapsen psyykkisiin tarpeisiin olemalla lasta kuunteleva ja tunteellinen. Taitojen kautta työntekijästä tulee pätevä ja hyvä ammattilainen. Ammattikohtaiset osaamiset tunnistetaan ja tuotetaan toimija koulutusalalle ominaisissa organisaatio- ja ammattirakenteissa, jotka perustuvat kulttuurisesti neuvoteltuihin toimi-, ammatti- ja koulutusalo- 
jen keskinäissuhteisiin. Vasta pohdittuamme ammatillisten osaamisten ydintä voimme kysyä, missä määrin niissä on yhteisiä piirteitä, jotka ovat otettavissa käyttöön muissa ammateissa.

\section{Sukириоlittamisen}

dikotomia

Genderqual-projektin pyrkimys kehittää eurooppalaista inhimillistä ja sosiaalista pääomaa ilmentää EU:n ohjelmapolitiikkaa. (EU commission 2000). Projektisuunnitelma painottaa naisellisina pidettyjen osaamisten ja taitojen tunnistamista ja tukemista, sillä ne ovat tärkeitä yhtäältä sosiaalisen kiinteyden voimistamisen ja syrjäytymisen torjumisen, toisaalta kollektiivisten tiedontuotannon, työnteon ja markkinakäytänteiden kehittämisen kannalta. Molemmat ovat perustavia EU-alueen talouden ja tuotannon kilpailukyvylle maapalloistuvilla markkinoilla.

Suomessa on vahva työmarkkinoiden ja koulutuksen sukupuolittumista koskeva tutkimus, mutta sitä ei ole helppo hyödyntää Genderqualtutkimuksessa. Eurooppalaisen gender-diskurssin osana senkin lähtökohtiin kuuluu yhtäältä sukupuolen tulkinta sosiaalisesti rakentuvaksi ja toisaalta sen tarkasteleminen yhden, yleensä naissukupuolen kannalta. Jo "gender"-sanaan sitoutuminen korostaa sosiologista, sosialisaationäkökulmaa kasvuun ja kasvatukseen. Sosiaalinen sukupuoli ilmenee rooleina, joita ovat myös työ ja ammatti. Sukupuoli-identiteetin voi tulkita sukupuoliroolin yksityiseksi kokemukseksi ja sillä voi kuvata ihmisen sosiaalisen mieheyden tai naiseuden yhtenäisyyttä, vahvuutta ja pysyvyyttä (Cameron, Moss \& Owen 1999, 8). Mieheys ja naiseus voi ilmetä monilla elämänalueilla ja eri ilmiöissä, kuten ammateissa, kielessä, perheja ystävyyssuhteissa sekä yksilöiden omien kokemusten kautta. Työssä ihmisen voi nähdä esittävän koko sukupuoli-identiteettiään eli erilaisia rooleja, tehtäviä ja tapojaan olla nainen tai mies.

Osaamisten ja taitojen tutkimisessa joudutaan helposti kehään, jos niiden dikotomian tulkitaan rakentuvan sosiaalisesti sukupuolen perustalta (sukupuolittuminen), ja sukupuolen edelleen olevan sosiaalisesti rakentunut. Genderqual- tutkimuksen kannalta ydinosaamisdiskurssin sukupuolisokeutta vastaa gender-diskurssissa ammatillisen osaamisen ja taitojen subsumoiminen sukupuolittuneiden työmarkkinoiden ja yhteiskunnallisten asemien - tai nais/miesolemuksen - esiintymiksi. (esim. Anttonen\&al 1994, Pateman 1988, Irigaray 1996.) Keskusteluissa on käynyt ilmi myös gender-diskurssin universaali ja abstrakti, vallitsevasti angloamerikkalainen sanasto ja tulkinnat, jotka eivät vastaa kulttuurisesti eriytyneitä merkityksiä. Suomen kielessä sana sukupuoli ei perinteisesti erottele sen eri muotoja ja on perustavasti yhdistynyt ihmissuvun jatkamiseen. Suvunjatkamiskyvyn yhteisöllisessä saavuttamisessa ja osoittamisessa on seksualiteettia tärkeämpää ollut aikuisille miehille ja naisille ominaisten työsuoritusten hallinta: sosiaalista sukupuolta on rakennettu työnjaolliseen yhteisöön osallistumisen kautta (Apo 1995, Tuohinen 1996, Löfström 1999, Heikkinen\&al 2001).

Kasvatuksellinen ja kulttuurinen tulkinta sosiaalisesta sukupuolesta kysyy niitä ajallisesti ja paikallisesti monikerroksisia, muuntuvia yhteyksiä suvunjatkamiskyvyn, seksuaalisuuden ja työnjaollisten ominaisuuksien välillä, joita ihmiset yhteisöissään pitävät oikeina/väärinä ja hyvinä/ pahoina. Jo yhteyksien nimeämistä sukupuoleksi voi pitää pahana, jos sillä tarkoitetaan suvunjatkamis- ja työnjaollisten ominaisuuksien ja seksualiteetin ehdotonta tapaa yhdistyä toisiinsa. Erojen ja vastakkaisuuksien paljastamisen ja naisen "toiseuden" sementoimisen lähtökohta tekee vaikeaksi tarkastella "ihmisten" ominaisuuksia sitoutumatta sukupuolijakoon. Sosiaalisen sukupuolen voi tulkita myös ihmisyyden (yksilöinä, kollektiiveina/yhteisöinä, ihmiskuntana) kulttuuriseksi ja historialliseksi olomuodoksi. Genderqual-tutkimuksessa keskeistä on sen koostuminen tietyistä osaamisista ja taidoista, seksualiteetista ja suvunjatkamisominaisuuksista, ihmisten yksilöllisen elämänkulun, työelämän ja koulutuksen kohtaamisissa.

Genderqual-projektin otsikossa kasvatus on dekontekstualisoitu ja ekonomisoitu. Sen sijaan ehdotamme talouden ymmärtämistä kulttuurisena ja antropologisena ilmiönä, elämänkeino- 


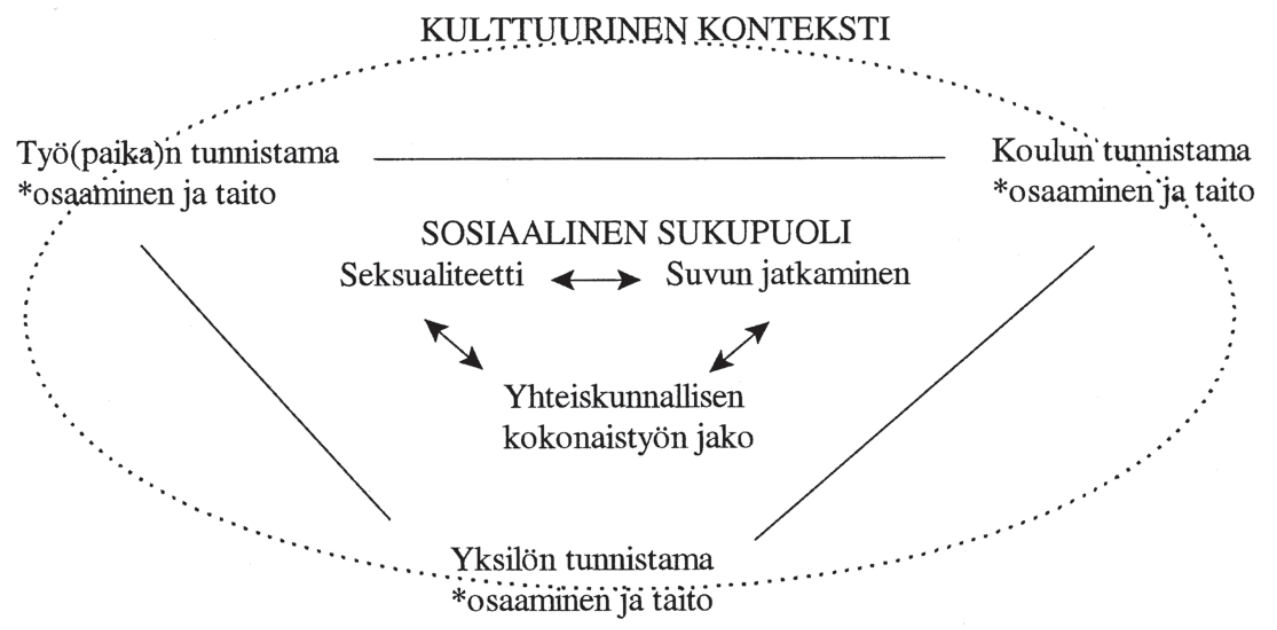

KUVIO 1. Ydinosaamisen sukupuolittumisen tutkimusasetelma

jen yhteisöllisenä uusintamisena (Narotzky 1997), johon kasvatuskin perustuu. Heuristisen mallin tarkoitus on tukea kulttuurisesti sensitiivisen, gender- ja osaamistutkimusta yhdistävän tulkintakehyksen työstämistä.

\section{PÄIVÄHOITAJAN, KOKIN JA SÄHKÖASENTAJAN OSAAMISEN SUKUPUOLI}

Käsitysten ja käytänteiden vertailun piti perustua tapaustutkimuksiin työpaikoilla ja ammatillisissa oppilaitoksissa havainnoimalla opetus- ja työtilanteita, haastattelemalla opiskelijoita, opettajia, työntekijöitä, työnantajia ja poikkeavan ammatinvalinnan tehneitä sekä analysoimalla dokumentteja, kuten opetussuunnitelmia, työohjeita ja työpaikkailmoituksia. Suomalaiset ryhtyivät yhteistyöhön palvelualojen, sosiaali- ja terveysalan ja teknisen ammattioppilaitoksen sekä niiden harjoittelupaikkojen - päiväkodin, ravintolan ja LVI- ja sähkötekniikan yrityksen - kanssa, mutta toiset alkoivat kerätä yksilöaineistoja. Havainnoinneissa tarkkailtiin mm. pukeutumista, keskustelun aiheita, miesten ja naisten välistä työnjakoa, työtapoja ja työtehtäviä. Haastattelujen teemoja olivat mm. hyvä ammattilainen/ ammatti, ammatissa keskeiset osaamiset ja taidot, ammatillinen kasvu ja uralla eteneminen, oma suhde työhön ja työn sukupuolittumiseen.
Haastattelujen odotettiin välillisesti kertovan myös sukupuolittavista käytänteistä. Opettajien kanssa on käyty ryhmäkeskusteluja heidän kokemuksistaan ammatillisissa uudelleenkoulutustilanteissa. Aineiston tulkinnoista keskustellaan oppilaitosten ja työpaikkojen edustajien kanssa.

Seuraavat haastatteluista nousevat luonnehdinnat päivähoitajan, kokin ja sähköasentajan ammatillisista osaamisista ja taidoista sekä niiden sukupuolittumisesta antavat vihjeitä kasvun paikkojen ja asemien eroista ja yhtäläisyyksistä. ${ }^{2}$

\section{P̈̈IV̈̈нOITAJA: lapsen ja perheen hyväntekijä}

Suomalaisen päivähoitajan ammatillisessa kasvussa oppilaitoksesta ja työpaikasta on tullut erillisiä ympäristöjä. Kouluopinnot täydentyvät aidossa päiväkotiympäristössä tapahtuvalla työharjoittelulla. Niinpä oppilaitoskäytänteet eivät simuloi työpaikkakäytänteitä.

Päivähoitajan työ nähtiin positiivisena ja myönteisenä työnä: työskentely lasten ja heidän vanhempiensa kanssa on antoisaa. Hyvät sosiaaliset taidot ovat oleellisia päivähoitajan työssä, sillä päivähoitaja tekee yhteistyötä lasten, vanhempien, muun henkilökunnan ja päiväkodin ulko- 
puolisten tahojen kanssa. Jos päivähoitaja ei tule toimeen erilaisten ihmisten kanssa, niin silloin hän on ilman muuta väärällä alalla.

"Joo, että se on musta semmonen ammattitaidon yksi tärkeä osa-alue, että pystyy kohtaamaan toisen ihmisen ja olemaan sympaattinen ja empaattinen ja kaikkea muuta. (opettaja)

"No tarvitaan ne perusvalmiudet, että osaa toimia ja olla sosiaalinen ja huomioida toisia ja kuunnella sitä lasta." (päivähoitaja)

Päivähoidossa tarvitaan joka päivä tietoa lasten fyysisen, psyykkisen ja sosiaalisen hyvän edellytyksistä, sillä sen avulla lapsille voidaan taata hyvä perushoito. Päivähoitaja on vastuussa lapsen perustarpeiden turvaamisesta: lapsella tulee olla lämmin ja hänen täytyy saada riittävästi ruokaa ja unta. Vasta tämän jälkeen tulevat opettaminen ja pedagogiikka. Päivähoitajalle on etua, jos hän on musikaalinen, liikunnallinen tai taiteellinen. Hän pärjää ilman erikoistaitoja, mutta haastateltavat kokivat, että päivähoitajan olisi hyvä hallita vähän musiikkia, liikuntaa ja kuvaamataitoa, ja olla avarakatseinen ja rohkea niiden toteuttamisessa.
"Kyllähän tässä tarvitaan sellaisia taitoja mitä, esimerkiksi osaa perushoitaa lasta ja sitten, että on tällaisia luovia, osaa ohjata lasten toi- mintaa... liikuntaa, musiikkia, luovaa ilmai- sua, eri tyyppistä." (opettaja)
"No tietysti on hyvä, jos on jotain erityis- taitoja, mutta yhdessä me tätä tehdään. Mei- tä on täällä kolme aina tekemässä, niin kyllä sitä osaamista aina löytyy.” (päivähoitaja)

Päivähoidon ammattilaisen tulee olla perhe- ja lapsilähtöinen toiminnassaan sekä ottaa huomioon yhteiskunnan vaikutukset siihen. Organisointikyky ja tietynlainen pitkäjänteisyys ovat myös hyväksi. Haastattelujen mukaan hyvä päivähoitaja on innostunut, luova, työnsä osaava, empaattinen, vastuuntuntoinen, auttamishaluinen, ihmisläheinen, iloinen, työhön sitoutunut, avoin ja oppimishaluinen. Päivähoitajan osaaminen ja taidot painottuvat vähemmän konkreettisiin kädentaitoihin kuin sosiaaliseen kanssakäymiseen muiden kanssa.

Päivähoitajan työ on melko huonosti palkattua, jonka vuoksi miesten arvellaan hakeutuvan alalle vähän. Myös ammatillinen eteneminen on heikkoa ja se vähentää miesten määrää. Ala on muutenkin perinteisesti naisia kiinnostavaa ja suosivaa. Kuitenkin miespäivähoitajat ovat suosittuja lasten ja vanhempien keskuudessa. Miehet nähdään päivähoidossa suurpiirteisempinä ja rohkeampina kuin naiset. Miehet myös "puuhaavat" enemmän lasten kanssa. Naiset taas ovat vuorovaikutussuhteissaan monimutkaisempia, pyrkivät syvällisempään kommunikaatioon ja ovat tunteellisia. Naiset myös ottavat yleensä kokonaisvastuun päiväkodin arjesta.

"Poikien kohdalla se (palkka) ehkä vaikuttaa enemmänkin, se karsii ainakin sitten sellaisia poikia." (opettaja)

"Se semmonen käytännön huolto, vaatehuolto ja käytännön asiat, niin kyllä ne enempi kaatuu naisille.” (päiväkodinjohtaja)

Päivähoitoalalla tarvitaan joitakin sellaisia piirteitä, jotka voidaan nähdä tyypillisempänä naisille. Tällaisia ovat mm. läheisyydensietokyky ja suvaitsevaisuus. Myös hoiva, huolenpito ja empaattisuus ovat naisilla enemmän "pinnalla". Miesten sopimattomuutta kuvataan voimakkaasti moralisoiden.

"No jos mies on niin, kun vanha sanonta sanoo, että viina, kirves ja miten se menee, ikinä en tanssi enkä puhu enkä halaa ketään, niin sittenhän sitä on vaikea olla alalla." (miesopiskelija)

"Ainahan sitä sanotaan, että hoivaa äidillisesti tai siihen tulee sellainen hoiva. On se kumminkin naisilla semmoinen hoivaava. Että kyllähän se luonnostaan.” (miespäivähoitaja) "Täällähän ollaan koko ajan toisia lähellä ja joku koskettaa sua, niin siitä pitää pitää." (päivähoitaja)

\section{KOKKI: iloluontoinen hyvän ja terveellisen ruoan tekijä}

Viin ravintola- kuin suurtalouskokinkin koutisten ja käytännöllisten opintojen integrointi. Aidon kokintyön simulointi tai oikea asiakastyö on elimellinen osa kouluopintoja.

Kokin ammatissa on osattava ruoanvalmistuksen 
eri osa-alueet ja vaiheet, on oltava kiinnostunut hyvästä ruoasta ja on oltava fyysisesti hyväkuntoinen. Työn nopeatempoisuus ja muuttuvat tilanteet vaativat nopeutta, stressin sietoa, kykyä hallita monia tehtäviä samanaikaisesti ja sopeutuvuutta.

"Hermot pitää olla ihan älyttömän hyvät, fyysinen kunto pitää olla kohtuullisen hyvä. Työ on oikeastaan ruumiillisestikin yllättävän raskasta ja pääkoppaan se käy kanssa. Kuitenkin rauhallinen ja ripeä." (mieskeittiöpäällikkö)

"Ravintolakokilta vaaditaan hyvin paljon sitä, että vahvaa ammattitaitoa, hirveän vahvaa. Ja sitten se, että pitää olla joustava ja olla valmis muuttuviin tilanteisiin eli se joustavuus tulee sitä kautta." (opettaja)

Ammatin vaatimat perustaidot toivat esille matemaattiset valmiudet sekä erikoisruokien osaamisen. Kansainvälisyyden lisääntymisen myötä myös kielitaito nähtiin tärkeänä. Kokki ei tee työtä yksikseen keittiössä, jonka vuoksi kokin tulee hallita myös asiakaspalvelu ja yhteistyötaidot. Myös organisointikyky on tärkeää.

"Tietysti ammatilliset aineet, mutta myöskin käytännön työ. Se kai varmaan on, mutta ei pidä unohtaa tänä päivänä laskentatoimea. Ja sitten tuo mikä mä olen kokenut myöskin, että kansainvälisyys on hyvä, että joka ainoan ravintolakokin pitää kyllä hallita yksi tai kaksi kieltä ja ammattisanasto." (opettaja) "Monesti joutuu käymään asiakkaiden kanssa läpi eri vaihtoehtoja, tekemään menuehdotelmia ja asiakaslähtöisesti katselemaan." (mieskeittiöpäällikkö)

Kokki vastaa ruoan laadusta ja terveellisyydestä. Ruokaa täytyy olla riittävästi, sen täytyy olla hygieenisesti valmistettua ja laadukasta. Kokin tulee myös vastata siitä, että ruoka-ainekustannukset ovat asianmukaiset. Vastuu on lisääntynyt viime vuosina, sillä välitason esimiehet ovat poistuneet. Alan arvostus on noussut vuosi vuodelta yhä enemmän. Siihen arvellaan vaikuttaneen suositut alaa käsittelevät televisio-ohjelmat ja kuluttajien lisääntynyt tietoisuus alasta. Millainen on hyvä kokki? Hän on avarakatseinen, iloinen, rauhallinen ja huumorintajuinen. Hän on vastuuntuntoinen, huolellinen, tarkka ja siisti. Hyvällä kokilla on myös hyvä stressinsietokyky ja hän on kätevä käsistään. Ala vaatii siis melko monipuolista osaamista ja tämän osaamisen hyödyntämistä erilaisissa tilanteissa.

Ravintola- ja suurtalousalalla toimii sekä miehiä että naisia, mutta naiset sijoittuvat yleisemmin suurtalouteen, miehet hakeutuvat enemmän ravintoloihin. Miesten ja naisten tavat toimia kokin ammatissa olivat kuitenkin erilaiset. Miehet tekevät tyypillisemmin alalla olevia raskaita töitä. He haluavat myös tehdä nopeasti valmistuvia ruokia, jossa toiminta on nopeaa ja hektistä. Miehet ovat työssään itsevarmempia ja kestävät kiirettä ja stressiä paremmin kuin naiset. Naiset taas ovat pitkäjänteisiä, ahkeria ja luotettavia. Naiset hallitsevat siisteyden ja esteettisyyden, mikä tulee esille työympäristön viihtyisyytenä ja ruokien esille laitossa. Miehet etenevät naisia paremmin ammattiuralla. Tähän saattaa vaikuttaa perheellisyys.

"Kyllä me kaikki pidetään tasa-arvoisina ja kaikki tekee kaikkea. Mutta siinä se, kyllähän se kädenjäljessä näkee sen. Ja siisteydessä näkee sen onko nais- vai mieskokki." (kokki) "Pojat on semmoisia rohkeampia ja jos ajattelee keittiötoiminnoissa, niin he ovat suuntautuneet tämmöiseen raskaampaan, nopeaan ruoan valmistukseen." (opettaja)

"Naisilla on semmoista silmää minkälainen on nätti ja siro." (opiskelija)

"Kyllä ne miehet. Tämä on se ikuisuus kysymys, että se on edelleenkin mysteeri, selittämätön asia miksi parhaat kokit on miehiä. Voi olla, että heillä ei ole perhesyitä niin paljon. Että vaimot ovat sitten kotosalla ja hoitavat sitä kotityötä ja miehet voivat tavallaan satsata siihen menemiseen ja kulkemiseen ja esillä olemiseen.” (opettaja)

\section{Sähköasentaja: harkitseva, näppärä ja sopeutuva}

Uumalaisen sähköasentajan kasvuprosessissa Skoulu ja työpaikka ovat erkaantuneet toisistaan, vaikka työssä oppimisen vaatimus onkin muuttamassa tilannetta. Insinöörit opettavat nuorille koulussa sähkötekniikan perusteita ja ohjaavat laboratoriotöitä, minkä jälkeen he vasta ovat 
kohdanneet sähköasentajien ammattikunnan ja työkäytänteet. Ellei sähköasentaja ryhdy yksityisyrittäjäksi, hän usein jatkossakin työskentelee työyhteisöissä, joita leimaavat teknisen työn koulutushierarkiat: insinöörisuunnittelijat ja -johtajat, vähintään teknikon koulutuksen saaneet työnjohtajat ja usein työntekijäporukasta valikoituneet kärkimiehet, jotka vastaavat kulloistenkin töiden konkreettisesta jakamisesta ja sujumisesta.

Kaikki haastatellut iästä, sukupuolesta ja paikasta riippumatta pitävät sähköasentajan osaamisen perustana sisäistä kiinnostusta sähköteknisiin ilmiöihin. Sähköasentajan osaaminen asettuu pitkälti itse toimialan ja ammattityön tilanteesta. Työssä on monia osa-alueita ja sitä tehdään hyvin erilaisissa olosuhteissa. Siksi asentajan on yhtäältä osattava tyypillisimpien sähköteknisten töiden perusteet, mutta toisaalta oltava erityisosaaja jollakin alueella ja hänen on osattava tehdä työ vaihtelevissa ympäristöissä ja tilanteissa. Sähköteknisten laitteiden ja järjestelmien kanssa työskentely edellyttää tarkkuutta sekä huolehtimista omasta ja työtulosten turvallisuudesta. Työtä tehdään sekä yksin että ryhmissä, mutta joka tapauksessa on osattava olla oma-aloitteinen ja otettava toiset huomioon.

"Jos ei kerta kaikkiaan kiinnosta... Jos on semmonen vähä höselö niin ehkä ei semmone kai." (opiskelija)

“(Jotkut) puhuu, että sähkötyö on siistiä ja heleppoo, mutta välillä se on hirveän raskasta ja erittäin huonoissa olosuhteissakin... kun isossa kiinteistössä vedetään esimerkiks vahvoja kaapeleita ja muuta ni kyllä se on tosi raskasta... Semmonen on varmaa aika kielteine ominaisuus... jos ei sopeudu erilaisiin olosuhteisiin." (miesasentaja)

"Se on perinteisesti ollu nää tiedot, taidot ja asenteet... tietoa sen verran, että Ohmin lain muistaa ja sitte tämä $\mathrm{P}=\mathrm{UxI}-\mathrm{kaavan}$, että kytketää joku laite sinne sähköjohdon päähän, ni paljonko se ottaa sähkötehoa, ni että palaako sulakkeet vai ei... Ettei vaarallinen itsellensä tai sitten työympäristölle.” (miesopettaja)

Hyvässä sähköasentajassa taitavuus yhdistyy tiettyihin luonteenpiirteisiin. Kaikki haastatellut arvelevat hyväksi ja taitavaksi yhteistyökykyisen, vastuullisen, oma-aloitteisen ja ahkeran ammattilaisen. Erityisen taitavat ovat näppäriä, loogisia ongelmanratkaisijoita, pitkäjänteisiä ja harkitsevia ja heillä on halu kehittyä ja oppia.

"kun joutuu tekemään yhteistyötä työkavereiden ja... muiden ammattiryhmien kanssa ni semmonen yhteistyökyky... semmonen hyvin itsekäs, äkkipikainen kaveri tietysti joutuu monta kertaa törmäyskurssille." (miesasentaja)

"kuka siinä on huippukaveri niin kyllä sillä älyäki pitää... ku ne ei oo aina helppoja, piirikaaviot ja kytkentäasiat... Se tyssää monella se viimesen päälle oleminen siihe, että ne ei pysty sitä hahmottamaan sitä kokonaisuutta sillä tavalla, että mitä tapahtuu, jos mä tuon teen.” (miesprojektipäällikkö)

Vaikka kaikki haastatellut pitävät sähköasentajan työtä, osaamisia ja taitoja samoina niin miehille kuin naisille, ilmaisevat he ohimennen tai pyydettäessä niissä ilmenevän joitakin eroja. Miehet yhdistävät miehisyyteen työn joidenkin osa-alueiden raskauden, olosuhteiden fyysisen epämiellyttävyyden ja ajallisen ja paikallisen vaihtelevuuden. Insinöörit ja esimiehet näkevät sukupuolittumista myös ajattelussa, oma-aloitteisuudessa ja itsenäisyydessä, jopa päinvastoin kuin työntekijät. Kun edelliset korostavat abstraktia loogista ajattelua, autonomiaa ja neuvoja kyselemättömyyttä, jälkimmäiset pitävät parempana halua kysellä neuvoja ja tehdä yhdessä toisten kanssa. Toisaalta kaikki aikuiset ja kokeneet ammattilaiset pitävät miehisenä ongelmana huolimattomuutta, piittaamattomuutta turvallisuudesta ja siisteydestä: pojat ja nuoret miehet pyrkivät siirtämään sosiaalisen sukupuolen mallia kotityön jaoista ammattityöhön.

"(Naurua) Sanosinko niin yksinkertasesti, että se loogine ajattelukyky... että naisen logiikka ei aina toimi sillä tavalla."

(miesprojektipäällikkö)

"Ei kukaan varmaan tee sitä ratkasua pojistakaa lähteä sähköasentajaksi sen takia, että ku se on niin miehinen ala", mutta "kyllä ne vetoaa siihe, että joo eihä siellä rakennustyömaallakaa ite siivota, sähkö-asentajat siivoa, vaan siellähän on rakennussiivoojat." (miesopettaja)

Sähköasentajan työssä hyvät, osaavat ja taitavat 
naiset ovat niin miesten kuin naistenkin mielestä hiukan erilaisia. Muut naiset suostuvat siisteihin, vain näppäryyttä vaativiin, rutiininomaisiin ja kevyisiin tehtäviin, mutta nämä eivät kaihda pimeitä, raskaita ja vaihtelevia olosuhteita, ovat suorapuheisia ja reippaita, eivät pelkää sähköä. Naisellisempia osaamisia ja taitoja ovat yleisesti tunnollisuus, siisteys ja turvallisuudesta huolehtiminen. Naiset arvelevat, että he voisivat kuitenkin olla myös järjestelmällisempiä ja kokonaisuuksia paremmin ymmärtäviä.

"On likaiset olosuhteet, on pimeetä,... raskasta... se on niin vaihtelevaa... että se ei ehkä houkuttele naisia... Aikonaan tehtiin tossa Jyväskylän jäähallia... oli meilläki semmonen tyttö... siinä harjoittelijana... Alkuun oli semmonen hiljanen ja kyräili ja katteli, ku tietysti semmonen isoon miesporukkaa joutuu ja tietystihä miehet aina yrittää kaikennäköstä herjaa heittää ja nuoren tytön tämmöstä hellää luontoo kokeilla ja muuta, mutta ku se vaihe meni ohite, ni kyllä tuli nii napakasti takasi ja oli siinä esimerkiks yhden kaverin kanssa ni kaapelinvedossa... ni oli erittäin ketterä liikkumaan... Meni sinne korkeelle... että esimieshenkilönä hän ois ollu erittäin sopiva, mutta hän oli vaan menossa opistoon opiskelemaan."(miesasentaja)

"Miehillähä on se kanssa, että ne ei ... mielellään tämmöstä vaihetyötä viitti ruveta sitten tekemään... tietysti naiset enempihä ne vempeleitä pelkää, että varsinki sähkölaitteita.. niistä voi saada sähköiskuja... Voihan olla, että ne on tunnollisempia kuitenkin sitten, että eivät tekisi ehkä näitä kaikennäkösiä viritelmiä, että koittas tehä nämä hommat vähä tunnollisemmin ja turvallisemmin." (miesopettaja)

"Sitte ku osaa ni on mukava tehä semmosta, ku moni just nainen esimerkiks, ni ei ne osaa."(opiskelija)

Sähköasentajan ydinosaamisen - kiinnostuksen sähköteknisiin ilmiöihin - viriämiselle on kasvuympäristöjen otollisuus, kavereiden tai omaisten esimerkki ja kannustus ollut ratkaisevaa. Yhdelle se merkitsi yhteisiä teknisiä leikkejä hiekkalaatikolla, toiselle innostusta koulun fysiikan opetukseen, jollekulle kotitalon sähköistystä tai työkaverin kannustusta kokeilemaan. Miehisten stereotypioiden varassa hakeutuneita oppilaita on ammattikoulun käytännöissä vaikea motivoida niukoilla ja joustamattomilla aika-, aineellisilla ja opetusresursseilla. Sekä oppilaat että opettajat toivoisivat systemaattisempia, suunnitelmallisempia ja teorian ja käytännön tehokkaammin yhdistäviä opintoja. Yhä harvemmalla opettajalla on kuitenkin sähköasentajan koulutus- tai työtausta: heillä on insinöörinäkemys sähköasentajuudesta eivätkä he voi toimia ammattilaisen mallina opiskelijoilleen.

"Must tuntuu, että naiset ehkä olis vähä järjestelmällisempiä... olis vielä hyvä, että... samantien sitten mentäs tekemää se työsalin puolelle ja ettei se unohu... mä epäilen, että jos olis naisia niin saattas ehkä toteutuaki." (opiskelija)

Työpaikoilla työntekijän osaamisen kehittymiseen vaikuttavat oman toiminnan ohella työporukka ja sähköteknisen toimialan ammatilliset ja organisatoriset hierarkiat. Suunnittelu-, johtamisja työntekijäasemat on usein erotettu toisistaan myös työ- ja sosiaalitilojen avulla. Jo eteneminen kärkimieheksi riippuu usein siitä, kenelle esimies antaa haasteita ja ketä kannustaa, mutta myös porukka itse ja etenkin kärkimies voi kontrolloida yksilön kehittymistä. Sähköteknisen työn projektimaisuus antaa toisille kehitysmahdollisuuksia, mutta voi jättää toiset hanttihommiin. Vaikka joustaviakin työpaikkoja on, koulutus tukee organisaatioasemien eriytymistä. Naisten kannalta tämä on ongelmallista, sillä monet etenevät koulusta suoraan esihenkilöiksi: työntekijät eivät saa kokemuksia naisista omassa työssään ja suhtautuvat epäilevästi esihenkilönaisten kykyyn ymmärtää heidän työtään.

"Se on niinku ennen jääkiekkojoukkuetta huudettii aina, ku mentii kaukaloo, ni kaikki meni rivii ja kaks kaveria tuli ulos ja rupes huutamaan sitä, minä otan sinut, sitte toise vuoro. Samallai tässäki käy elikkä siinä hyvi äkkiä nähhää (työnjohto), ketkä on ne, jotka tekee ja ketä halutaa.” (miesprojektipäällikkö)

"mut ku täällä ei oo yhtää naista, ni ei se toimi. Täällä aatellaa, että mites pirusta se voi tietää, ku ei täällä ees yhtää naista oo ollu kahteenkymmenee vuotee... Mutta sähköalakin, että jos siellä ois naisia joukossa reippaasti, ni kyllähä se kiinnostavampi ois."(miesprojektipäällikkö) 
TAULUKKO 1. Esimerkkejä osaamisesta ja taidoista

\begin{tabular}{|c|c|c|c|}
\hline & Päivähoitaja & $\begin{array}{l}\text { Kokki(suurtalous-ja } \\
\text { ravintola-ala) }\end{array}$ & Sähköasentaja \\
\hline $\begin{array}{l}\text { OSAAMINEN } \\
\text { (osaamisalueet) } \\
\text { YHIEINEN }\end{array}$ & $\begin{array}{l}\text { * lasten perushoito: } \\
\text { psyykkinen ja fyy- } \\
\text { sinen hoiva }\end{array}$ & $\begin{array}{l}\text { * ruuanvalmistuksen } \\
\text { perusteet } \\
\text { * sosiaalisuus }\end{array}$ & $\begin{array}{l}\text { * kiinnostus sähkötekni- } \\
\text { siin ilmiöihin } \\
\text { * hyvä fyysinen kunto } \\
\text { * alan jatkuva seuraaminen }\end{array}$ \\
\hline $\begin{array}{l}\text { Ammatilliset } \\
\text { oppilaitokset }\end{array}$ & $\begin{array}{l}\text { * luovuus } \\
\text { * ihmisläheisyys } \\
\text { * motivaatio alalle } \\
\text { * kärsivällisyys }\end{array}$ & $\begin{array}{l}\text { * sosiaalisuus } \\
* \text { joustavuus } \\
\text { * siisteys } \\
\text { * tekee asiat nopeasti } \\
\text { * kärsivällisyys }\end{array}$ & $\begin{array}{l}\text { * asennus, huolto, korjaus } \\
\text { * sähkötekniikan perusteet } \\
\text { * sähkötekninen lukutaito } \\
\text { * osaamisen päivittäminen } \\
\text { * myös erityisala } \\
\text { * ryhmässä työskentely } \\
\text { * järjestys, turvallisuus, } \\
\text { siisteys } \\
\text { * jousto (ajat, paikat, tehtävät) }\end{array}$ \\
\hline $\begin{array}{l}\text { TADOT } \\
\text { YHIENEN }\end{array}$ & $\begin{array}{l}* \text { puhelias } \\
* \text { tunteellinen }\end{array}$ & * kätevä käsistään & $\begin{array}{l}* \text { oma-aloitteinen, ahkera } \\
* \text { harkitseva, loogisesti } \\
\text { ajatteleva } \\
\text { * näppärä }\end{array}$ \\
\hline $\begin{array}{l}\text { Ammatilliset } \\
\text { oppilaitokset }\end{array}$ & $\begin{array}{l}\text { * kätevä käsistään } \\
\text { * musikaalinen } \\
\text { * hellä, rauhallinen } \\
\text { * kärsivällinen } \\
\text { * kuuntelija }\end{array}$ & $\begin{array}{l}* \text { palvelualtis } \\
* \text { huolellinen } \\
* \text { oma-aloitteinen } \\
* \text { puhelias } \\
* \text { organisoija }\end{array}$ & $\begin{array}{l}* \text { luotettava } \\
* \text { huolellinen, siisti } \\
\text { taiteellinen, } \\
\text { urheilullinen } \\
\text { * organisoija } \\
* \text { sosiaalinen, huumorin- } \\
\text { tajuinen, kärsivällinen }\end{array}$ \\
\hline
\end{tabular}

YDINOSAAJAT: kätevät,

kärsivälliset, sosiaaliset ja siistit organisaattorit

Seuraavat taulukot kokoavat osaamisen ja taitojen luonnehdinnat oppilaitoksissa ja työpaikoilla. Niistä ilmenee aito vaikeus erottaa ammattilaisten osaamista ja taitoja heidän luonteenpiirteistään ja ominaisuuksistaan.

Niin miehet kuin naisetkin luonnehtivat oman alansa osaamista ja taitoja hyvin samalla tavalla, niin myös niiden taulukkoon 2 koottuja suku- puolittuneita piirteitä. Kaikille aloille perustavana osaamisena pidettiin sosiaalisuutta, joskin sen sisältö vaihtelee ammateittain. Opetussuunnitelman perusteissa viestintä- ja yhteistaidot kuuluvatkin kaikkien ammattien ydinosaamiseen. Yhteisinä nousivat esiin myös organisointitaidot: oman työn järjestäminen ja sen muokkaaminen sekä työtehtävien jakaminen toisten kanssa. Yllättävä aloille yhteinen taito oli kätevyys, joka ilmenee sorminäppäryytenä ja kykynä tehdä tarkkaa työtä. Kädentaito ei tule esille ydinosaamisen suomalaisessa opetussuunnitelmadiskurssissa, sen enempää kuin eurooppalaisessa 
TAULUKKO 2. Esimerkkejä osaamisen ja taitojen sukupuolittuneisuudesta

\begin{tabular}{|c|c|c|c|}
\hline & Päivähoitaja & $\begin{array}{l}\text { Kokki(suurtalous- } \\
\text { ja ravintola-ala) }\end{array}$ & Sähköasentaja \\
\hline $\begin{array}{l}\text { OSAAMINEN } \\
\text { (osaamisalueet) }\end{array}$ & $\begin{array}{l}\text { Naiset } \\
* \text { sisäinen äitiys }\end{array}$ & $\begin{array}{l}\text { Naiset } \\
\text { * parempia puhtaana- } \\
\text { pidossa }\end{array}$ & $\begin{array}{l}\text { Miehet } \\
\text { * hyviä fyysisesti ras- } \\
\text { kaissa, epämiellyt- } \\
\text { tävissä töissä }\end{array}$ \\
\hline \multicolumn{4}{|l|}{ YHIENEN } \\
\hline Ammatillisetoppila & $\begin{array}{l}\text { *set } \text { Naiset } \\
\text { syvällisempiä kom- } \\
\text { munikaatiossa } \\
\text { * omaavat erityistaitoja }\end{array}$ & $\begin{array}{l}\text { Naiset } \\
\text { * parempia vastaamaan } \\
\text { kokonaisuudesta } \\
\text { * tekevät koko ajan }\end{array}$ & $\begin{array}{l}\text { Naiset } \\
\text { * kokoonpano-, vaihe- } \\
\text { ja asiakastyö } \\
\text { * järjestyksenpitäminen }\end{array}$ \\
\hline & $\begin{array}{l}\text { Miehet } \\
\text { * laajakatseisia ja } \\
\text { rohkeita } \\
\text { * parempia tekemään } \\
\text { uraa }\end{array}$ & $\begin{array}{l}\text { Miehet } \\
\text { * hyvä stressinsieto- } \\
\text { kyky }\end{array}$ & $\begin{array}{l}\text { Miehet } \\
* \text { itsenäiset työt }\end{array}$ \\
\hline TYÖРAIKAT & $\begin{array}{l}\text { Naiset } \\
* \text { huolellisuus ja tarkkuus } \\
\text { Miehet } \\
* \text { huolettomampia } \\
* \text { suoria kommunikaatiossa }\end{array}$ & $\begin{array}{l}\text { Miehet } \\
\text { * hyvä stressinsieto- } \\
\text { kyky } \\
\text { * parempia tekemään } \\
\text { uraa }\end{array}$ & $\begin{array}{l}\text { Naiset } \\
* \text { hyviä useimmissa } \\
\text { * hyvän työilmapiirin } \\
\text { luojia }\end{array}$ \\
\hline $\begin{array}{l}\text { TAIDOT } \\
\text { YHIEINEN }\end{array}$ & $\begin{array}{l}\text { Miehet } \\
\text { * leikkisiä }\end{array}$ & $\begin{array}{l}\text { Naiset } \\
\text { * esteettisiä, siistejä } \\
\text { Miehet } \\
\text { * vahvoja } \\
\text { * kärsivällisiä }\end{array}$ & $\begin{array}{l}\text { Naiset } \\
* \text { huolellisia, siistejä } \\
\text { Miehet } \\
\text { * matemaattisesti ja } \\
\text { teknisesti loogisia }\end{array}$ \\
\hline $\begin{array}{l}\text { Ammatillisetoppi- } \\
\text { laitokset }\end{array}$ & $\begin{array}{l}\text { Naiset } \\
* \text { työteliäitä } \\
* \text { sosiaalisia, puheliaita } \\
\text { Miehet } \\
\text { * suorasukaisia } \\
\text { * suurpiirteisiä }\end{array}$ & $\begin{array}{l}\text { Naiset } \\
* \text { luotettavia }\end{array}$ & $\begin{array}{l}\text { Naiset } \\
* \text { johdonmukaisia } \\
* \text { ristiriita: loogisia <-> } \\
\text { rutiininomaisia } \\
\text { Miehet } \\
* \text { omaperäisiä }\end{array}$ \\
\hline Työpaikat & $\begin{array}{l}\text { Naiset } \\
\text { * käytännöllisiä, äidillisiä } \\
\text { * miellyttäviä, suosittuja }\end{array}$ & & $\begin{array}{l}\text { Miehet } \\
* \text { sopeutuvia }\end{array}$ \\
\hline
\end{tabular}


poliittisessa tai tutkimusdiskurssissakaan. Kaikkien työt vaativat kärsivällisyyttä, mikä tarkoittaa kykyä keskittyä omiin tehtäviin, sopeutua muuttuviin ja vaihteleviin tilanteisiin ja työolosuhteisiin sekä malttia odottaa seuraavaa työvaihetta. Tärkeänä pidettiin myös siisteyttä työympäristöstä ja työn jäljestä huolehtimisena.

Naisia pidettiin kaikissa ammateissa siistimpinä kuin miehiä. Heidän nähtiin pyrkivän syvällisempään vuorovaikutukseen kuin miehet ja vaikuttavat yleensä positiivisesti työyhteisön ilmapiiriin, etenkin miesvaltaisella alalla. Miehillä korostuivat fyysiset osaamiset ja taidot ja heitä pidettiin suurpiirteisempinä ja loogisemmin ajattelevina ja toimivina. Haastatteluja tulee jatkossa lukea ammattiasemia, sukupuolia ja kasvun paikkoja vertaillen yhdistämällä ne havainnointeihin, dokumenttien analyysiin ja yhteistyökumppaneiden kanssa käytyihin vuoropuheluihin. Jo nyt näyttää kuitenkin siltä, että osaamiset ja taidot asettuvat (kulttuurisesti neuvotellusta) ammattityöstä itsestään ja naiset ja miehet nimeävät ne samoin; joissakin osaamisissa ja taidoissa miehiä ja naisia kuvataan erilaisiksi; jos erot ovat poissulkevia, ne asettuvat itse työstä ja naisten/miesten olemuksellisista eroista.

\section{Osaamisen ja sukupuolit- tamisen suomalaisuus}

Sosiaalinen sukupuoli koostuu työn, koulutuksen ja yksilöllisten elämänkulkujen kulttuurisesti erityisissä kohtaamisissa. Genderqual-tutkimuksessa korostuu kansallisten kulttuurien suhteuttaminen toisiinsa. Kaikissa maissa feminiinisyyttä ja maskuliinisuutta kuvataan stereotyyppisesti. (Kampmeier 2001) Tämä muistuttaa Merja Kinnusen (2001) väitöskirjassaan toteamaa yhdenmukaisuutta Simmelin, Turkan ja työelämän naistutkijoiden välillä: kaikille naisten osaamiset ja taidot ilmentävät heidän "sisäisyyttään” ja "suhteutumistaan toisiin", miesten taas heidän "ulkoisuuttaan" ja "autonomiaansa". Kehollisen ja sosiaalisen elämän ylläpitäminen, toisten ihmisten hoivan ja tuen vaatimukseen vastaaminen olisivat universaalisti sosiaalisille naisille kuuluvia, alempiarvoisia osaamisia ja taitoja. Ihmislajin hyvinvointia ja elämää välillisesti ylläpi- tävät, teknisiin ja taloudellisiin järjestelmiin kohdistuvat osaamiset ja taidot olisivat ylempiarvoisia ja kuuluvat sosiaalisille miehille.

Osaamisten ja taitojen sukupuolittumisen ymmärtämisessä yksittäisten ammattien tarkastelu ei riitä. Genderqual-tutkimuksen ammatit ovat osa suomalaisten ammattien ja toimialojen kokonaisuutta: päivähoitajan ammatillista osaamista ja taitoja määrittävät myös muut ammattiryhmät, erityisesti lastentarhanopettajat, sähköasentajan taas sähköteknikot ja -insinöörit ja muut teknisen työn ammattilaiset. Myös työorganisaation luonne - esimerkiksi onko kyseessä pienyritys vai kansallisen tai monikansallisen yhtiön osa vaikuttaa. Osaamisen sukupuolittamisen kontekstointi suomalaiseen ammatti- ja toimialojen järjestykseen edellyttää sen historiallistamista. Niin teknisen kuin hoiva-alan ammatillistumisessa on sukupuolipolarisaatioon liittynyt työn hierarkisoiminen ja eriyttäminen, jota koulumainen ja työpaikkojen kasvatus on tukenut. Hotelli-, ravintola- ja suurtaloustyössä erojen tekeminen ei ole yhtä keskeistä ja on jopa lieventynyt. Teknisellä ja hoiva-alalla hierarkian ylimpien ammattien ammatinkäsitykset ja -ihanteet ovat esimerkillisiä ja vaikutusvaltaisia, vaikka ne käytännössä sovitettaisiin alhaalta tuleviin. Ideaalit edustavat parempaa ja ylempää ja vaativat vertailukohdakseen huonomman ja alemman. Sähköasentajan ja päivähoitajan osaamisen ja taitavuuden kuvauksiin näyttää “valuvan” ilmauksia "ylemmistä" ammateista. Erityisesti tämä koskee opettajia ja työnantajan edustajia, jotka koulutukseltaan samaistuvat ylempiin.

Insinöörit ovat sähköasentajien "ylempänä” olleet kansallisen talouden avainryhmä, joka on vastannut tuotannon ja työprosessien tehokkuudesta, työntekijäarmeijan kontrolloinnista. Ihanteellinen insinööri on ilmentänyt autonomista, itseriittoista maskuliinisuutta: ei pyydä apua, ei pelkää, ottaa riskejä, on lojaali omilleen, ahkera, täsmällinen ja innovatiivinen. Vanhemmille insinööripolville ovat kansallinen hyvinvointi ja teknologisen infrastruktuurin turvallisuus olleet tärkeämpiä kuin nuoremmille, jotka arvostavat enemmän kilpailua ja kovuutta (ks. Heikkinen 2001). Sähköasentajien osaamisen ja taidon 
luonnehtima naisten "hienohelmaisuus", epäloogisuus ja tekniikan pelko ilmentää "alemmuutta". Hoivatyössä on ihanteellista ollut kansallinen äitiys, kansan ja maan hoivaaminen ja puolustus, enenevästi sen kasvattaminen ja psyykkinen ja fyysinen disiplinoiminen (emt., Henriksson 1998). Päivähoitajien osaamista ja taitoja kuvataankin usein naisten emotionaalisena ja moraalisena ylemmyytenä suhteessa miehiin. Osaamisten ja taitojen eriarvoisuus korostuu sähköasentajan ja päivähoitajan ammattikasvatuksessa, jossa työssä oppiminen on pidetty erillään koulusta. Opiskelijat eivät ehkä identifioidu asemaltaan ylempään opettajaan, mutta heidän odotuksiaan saattavat suunnata hänen ammatista välittämänsä maskuliiniset ja feminiiniset ominaisuudet. Nuorille voi olla erityisen tärkeää odotusten yhdistyminen seksuaalisiin ominaisuuksiin, jotka ovat keskeisiä heidän aikuistumisessaan. Ravintola- ja suurtalouskokeilla ammattiihanteet, "ylempi" ja "alempi" eivät ole niin sukupuolittuneita eivätkä kiinnity yhtä tiukasti koulutuseroihin. Opintojen sisään rakennettu osaamisten ja taitojen aito, mutta turvallinen, kokeileminen sekaryhmässä saattaa tehdä ammatillisen ja seksuaalisen identiteetin suhteuttamisen opiskelijoille avoimemmaksi ja helpommaksi.

Genderqual-projektin yritys tuottaa eurooppalaisia suosituksia osaamisen ja taitojen sukupuolittamisen ylittämiseksi näyttää kyseenalaiselta, kun jo termien kvalifikaatio, kompetenssi, taidot ja osaaminen määrittelyt ja käsitykset eroavat maittain. Erot viittaavat riippuvuuteen kulttuurisesta ja yhteiskunnallisesta kontekstista. Esimerkiksi vain Englannissa aloille yhteisiä avaintaitoja opetetaan erikseen ja vain Saksassa käytetään ilmausta avainkvalifikaatiot. Vaikka osaamiset ja taidot nimettäisiinkin samoin - yhteistyötaitoina, vastuullisuutena ja stressinsietokykynä - eivät ne tarkoita samaa eri maissa ja ammateissa. Koulutusrakenteet ja työnarvostus kytkeytyvät sukupuoleen eri tavalla Etelä- ja Pohjois-Euroopassa. Englannissa sähköalan työtä pidetään naisille sopimattoman likaisena ja raskaana ja miespuolisia päivähoitajia epäillään seksuaalisista perversioista. Kreikassa taas vanhemmat katsovat päivähoidon edellyttävän sellaista äidillisyyttä, joka on mahdollista vain naisille eivätkä suosi miespäivähoitajia. Vain Suomessa kaikki haastatellut pitivät ammatteja sekä miehille että naisille sopivina ja erojen tasoittumista hyvänä. Saksassa ja Englannissa esitettiin enemmän seksistisiä ja vähemmistösukupuolen yleistymistä vastustavia käsityksiä. Seksualiteetti onkin kaikissa maissa ilmennyt tärkeäksi osaamiseen liittyväksi sosiaalisen sukupuolen tekijäksi.

\section{Voiko osaamisen ja taitojen sukupuolittamista ylittää?}

Haastatteluista nousee oletus siitä, ettei ammatillisessa perus- ja aikuiskoulutuksessa tai työpaikoilla voi tehdä juuri mitään ihmisten "jo ennen" tai "jossain muualla” omaksumille käsityksille ammatillisten taipumusten ja mieltymysten yhteydestä biologisiin ominaisuuksiin ja seksualiteettiin. Sosiaalisen sukupuolen kehän nähdään sulkeutuvan jo lapsena, jolloin töiden, tehtävien, osaamisten ja taitojen sukupuolittaminen alkaa. Poikkeavien taipumusten tunnistamisessa on tärkeää se, että kodissa on osallistuminen kaikkiin töihin ja leikkeihin ollut avointa kaikille. Kun ammatillinen työ katoaa lasten ja nuorten kokemusmaailmasta, korostuu kaverien ja median merkitys aikuistumisessa ja ammatillisen identiteetin muotoutumisessa. Ammattia koskeva mielikuva voi osaamista enemmän vaikuttaa sen valintaan. Esimerkiksi catering-alalla työskentelee yhtä paljon miehiä kuin naisia, mutta hotelli- ja ravintolamaailma on ammatinvalintavaiheessa pojille vielä kiehtovien mielikuvien sävyttämää. Suurtalous on tuttua kouluruokalasta, jonka suihkumyssypäiset keittäjät eivät tee alaa houkuttelevaksi. Kuitenkin työ on hyvin samanlaista ja perustaidot melkein samoja.

Projekti on kiirehtinyt suosittamaan ydinosaamisen ja -taitojen sukupuolittamisen ylittämistä nimeämällä ne uudelleen. Jos ihmisiä voidaan vapauttaa biologian asettamista odotuksista määrittelemällä sukupuolia uudelleen, miksei ammattien sukupuolittuminen heikentyisi samoin? (Sipilä 1998, 29.) Mutta tavoitellaanko tällä vain EU:n ohjelmapolitiikan toteuttamista? Jos sukupuolittaminen merkitsee ihmisen hyvän ja elämän jatkuvuuden kokonaisnäkökulman katoamista, sitä voi pitää eettisesti vääränä, toteuttavatpa 
sitä miehet tai naiset. Suomalaisen aineiston perusteella näyttää, että monille ihmisille työ naistai miesvaltaisessa ammatissa antaa mahdollisuuden tehdä hyvää niin, että se sopii heidän kokemuksiinsa itsestään naisina ja miehinä. Poikkeavassa ammatissa työskentelevät näyttävät vahvoilta: he ovat purkaneet sosiaalisen sukupuolen suljetun kehän ja hyväksyvät seksuaalisuutensa, suvunjatkamisbiologiansa ja ammatilliset taipumuksensa. Onko heidän esimerkistään kuitenkaan malliksi itsestään epävarmoille ja syrjäytyville ihmisille, joiden koulutus- ja työuran vaihdon mahdollisuuksia Genderqual-tutkimus myös etsii.

Miten tukea ihmisten eettistä kasvua osallisiksi ihmissuvun ja elämän jatkumiseen, työnjaolliseen yhteiskuntaan ja vastuulliseen seksuaalisuuteen yhdistämättä niitä kohtalonomaisesti? Koulujen ja työpaikkojen mahdollisuudet purkaa sosiaalisen sukupuolen suljettua kehää voivat olla vähäiset, mutta niitä voisi edistää keskustelun syventäminen ja laajentaminen. Genderqual-tutkimuksessa se merkitsisi gender- ja ydinosaamisdiskurssin ja niiden keskinäisyhteyden uudelleen pohtimista. Edellisessä voisi toivoa, että maskuliinisen hegemonian vastaisen keskiluokkaisen naisohjelman rinnalla vahvistuisi sukupuolen tarkastelu suhdekategoriana sekä sellainen sukupuolittumisen kriittinen analysointi, missä sukupuolia suhteutetaan toisiinsa. Ydinosaamisdiskurssi voisi olla itsekriittisemmäksi pyrkimyksilleen yleisiin (generic) osaamisiin ja taitoihin. Onko kyse keskiluokkaisesta universaalin tasa-arvoisuuden, inhimillisen pääoman yksilöllisen kasvun edistämisestä, joka kuitenkin kohtelee yhteiskunnan ja työelämän eri asemissa olevia eriarvoistavin tavoin? Yksille se antaa mahdollisuuden osaamisen rajattomaan elinikäiseen kehittämiseen ja varmistaa toisten käytettävyyden "joustavina, päivittymiseltään optimaalisina yleiskoneina" (Castells 2000, 371).

Molemmissa diskursseissa sosiaalisen konstruktionismin kulttuuritonta lähtökohtaa voisi avata itse sosiaalisen kysymiselle kasvatusta koskevissa analyyseissä. Kasvatusantropologisesti sosiaalinen tarkoittaisi yksilöiden ja kollektiivien vastavuoroisesti ylläpitämää ja tavoittelemaa arvoa. Yksi- lötasolla se olisi toisten hyvän saavuttamisen arvostamista ja ilmenisi vastaavina luonteen ja toiminnan hyveinä. Kollektiivisesti sosiaalinen ilmenisi ihmisten välisen kanssakäymisen vastavuoroisuutena, toisten hyvää tavoittelevaan toimintaan osallistumisena. Sosiologian klassikotkaan eivät tarkoittaneet sosiaalisella vain "välinettä", jolla identiteettejä rakennetaan, vaan ihmisten välistä moraalin, vastavuoroisten velvollisuuksien ja tekojen aluetta. Ydinkompetenssien kannalta olisi kiinnostavaa ajankohtaistaa Durkheimin pohdinnat ammatillisesti organisoituneen työn perustavasta merkityksestä sosiaalisen muodostumiselle. Hän oli huolissaan kollektiivisten ammatillisen työn muotojen murentumisesta ja alistamisesta (liike)taloudellisille arvoille. Sosiaalisen kysyminen ydinosaamisten tai sukupuolittamisen ohella korostaisi osaamisten ja taitojen eettistä koettelua elämisen keinojen uusintamisen osana.

Osaamisten ja taitojen uudelleen nimeäminen antamalla teknisille osaamisille yhteisöllisiä ja hoivaavia nimiä ja hoivatyössä päinvastoin - voi hetkellisesti lisätä alojen houkuttavuutta. Mikäli ne eivät edes laadullisesti eroa miesten ja naisten kesken, voisi tärkeämpää olla antaa ihmisille mahdollisuuksia läpi elämän tunnistaa ja oppia (uudelleen) osaamis- ja taitotaipumuksiaan. Ammatillisessa perus- ja uudelleenkoulutuksessa voisi eri ammattialojen osaamisia kokeilla systemaattisemmin ja työpaikoilla antaa osaamisten erilaisuudelle tilaa. Jos jotkut ammatin ydinosaamiset ja taidot liittyvät poissulkevasti miehiin tai naisiin, voi perustavampi mieheyden ja naiseuden pohdinta olla tarpeen (mikä voisi tietysti johtaa erojen hyväksymiseenkin).

\section{Kirjallisuus}

AINLEY, P. (1993). Class and Skill. London: Cassel. ANTTONEN, A. \& Henriksson, L. \& Nätkin, R. (toim. 1994). Naisten hyvinvointivaltio. Tampere: Vastapaino.

APO, S. (1995). Naisen väki. Helsinki: Hanki ja Jää. ARNOLD, R. (1997). Schlüsselqualifikationen - Ziele einer Evolutionären Berufspädagogik. Teoksessa Arnold, R. (toim.). Ausgewählte Theorien zur beruflichen Bildung. Hohengehren: Schneider Verlag. 134-148.

CAMERON, C., Moss, P. \& Owen, C. (1999). Men in the Nursery: Gender and Caring work. London: Sage. 
CASTELlS, M. (2000). The Information Age: Economy, Society and Culture, volume III. End of Millenium. 2nd edition. Cornwall: Blackwell.

EU Commission 2000. A Memorandum on Lifelong Learning. Working paper 30.10.2000.

HEIKKINEN, A. 2001. Masters and Mistresses of the Nation. Teoksessa Gonon, P, Haefeli, K., Heikkinen, A., Ludwig, I. (eds) (2001). Gender Perspectives on Vocational Education. New York-London: Peter Lang. 279-304.

HEIKKINEN, A., Borgman, M., Henriksson, L., Korkiakangas, M., Kuusisto, L., Nuotio, P., Tiilikkala, L. (2001). Niin vähän on aikaa: ammatillisen kasvun katoava aika, paikka ja tila. Saarijärvi: RCVE.

HEIKKINEN, A., Korkiakangas, M. Kuusisto, L., Nuotio, P., Tiilikkala, L. (1999). Elinkeinon edistämisestä koulutuspalvelujen laadun tarkkailuun. Tampere: Ammattikasvatuksen tutkimuskeskus.

HENRIKSSON, L. (1998). Naisten terveystyö ja ammatillistumisen politiikat. Helsinki: STAKES.

IRIGARAY, L. (1996). Sukupuolieron etiikka. Tampere: Gaudeamus.

KAMPMEIER, A. (2001). Gender and qualification. Are gender differences ignored? Esitelmä ECER-konferenssissa Lillessä 8.9.2001.

KAUPPINEN-TOROPAINEN, K. (1991). Miehet naisvaltaisissa ja naiset miesvaltaisissa ammateissa: ainokaisaseman analyysi. Työ ja ihminen 5 (1991). Työympäristötutkimuksen aikakauskirja. Helsinki.

KELLY, A. (2001). The Evolution of Key Skills: towards a Tawney paradigm. Journal of Vocational Education and Training, 1/2001, 21-35.

KINNUNEN, M. (2001). Luokiteltu sukupuoli. Tampere: Vastapaino.

KOIVISTO, T. \& Koski, P. (1999). Asiakassuuntautunut, joustava ja verkottunut. Analyysi tuotantojärjestelmien ja osaamistarpeiden kehityssuunnista. Tuotantojärjestelmien organisatoriset ja sosiaaliset innovaatiot - tutkimusprojektin loppuraportti. ESR-julkaisut 54/99.

KOLEHMAINEN, S. (1999). Naisten ja miesten työt. Työmarkkinoiden segregoituminen Suomessa 1970-1990. Tilastokeskus. Tutkimuksia 227. Helsinki: Hakapaino.

LÖFSTRÖM, J. (1999). Se nyt vaan on sellainen. Sukupuoliero agraarikulttuurissa. Helsinki: SKS.

NAROTZKY, S. (1997). New Directions in Economic Anthropology. London-Chicago: Pluto Press.

NIJHOF, W. \& Streumer, J. (toim. 1998) Key Qualifications in Work and Education. Dordrecht: Kluwer.

Opetushallitus (2000). Ammatillisen peruskoulutuksen opetussuunnitelman ja näyttötutkintojen perusteet. http://www.oph.fi/ops/index.html. 5.5 2001 .

PATEMAN, C. (1988). The Sexual Contract. Cambridge: Polity Press.

POLANYI, M. (1983). Personal Knowledge. London: Routledge.

REETZ, L.\& Reitmann, Th. (toim.1990). Schlüsselqualifikationen. Fachwissen in der Krise. Hamburg: Feldhaus.

SILTALA, J. (1999). Sosiologinen ja psykologinen minä: minuus vuorovaikutuksen historiana ja tunnedynaamisena kokonaisuutena. Teoksessa Näre, S. (toim.) Tunteiden sosiologiaa, osa II. Helsinki: SKS. 371-465.
SIPILÄ, P. (1998). Sukupuolitettu ihminen -kokonainen etiikka. Onko sukupuoli oikein. Tampere: Tammer-Paino Oy.

Tilastokeskus (2001). Naiset ja miehet numeroina. $\mathrm{http}: / / \mathrm{ww}$ w.tilastokeskus.fi/tk/he/tasaarvo koulutus.html. 12.2.2001.

TUOHINEN, T. (1996). Isät, pojat ja pärjäämisen henki. Hoikkala, T. (toim.). Miehenkuvia. Välähdyksiä nuorista miehistä Suomessa. Tampere: Gaudeamus, 66-101.

WOLF, A. (1995). Competence-based assessment. Buckingham-Philadelphia: Open University Press.

\section{Viitteet}

Sukupuolittuminen painottaa ilmiön tapahtumista, sukupuolittaminen sen tuottamista.

2

Puhujasta on ilmaistu asema ja kasvun vaihe, miespuhujat erikseen.

Artikkeli saapui toimitukseen 20.9.2001. Se hyväksyttiin julkaistavaksi 31.10.2001. 